\title{
The Relationship Analysis between Service Performances of Milk Producer Cooperative with the Dairy Farm Performance of Members
}

\author{
A. Asmara ${ }^{\mathrm{a}, *}$, Y. L. Purnamadewi ${ }^{\mathrm{a}}$, \& D. Lubis ${ }^{\mathrm{b}}$ \\ ${ }^{a}$ Department of Economics, Faculty of Economics and Management, Bogor Agricultural University \\ ${ }^{b}$ Department of Sharia Economics, Faculty of Economics and Management, Bogor Agricultural University \\ Kampus IPB Darmaga, Bogor 16680, Indonesia \\ (Received 28-11-2016; Reviewed 08-03-2017; Accepted 21-06-2017)
}

\begin{abstract}
The main objective of Milk Producers Cooperative (MPC) is to provide services to the members and improve the performance of dairy farm of MPC members. The purposes of this study were: (1) to analyze dairy farm performance of MPC members, (2) to analyze performance of MPC services, and (3) to analyze the relationship between service performance of MPC with dairy farm performance of MPC members. The main data used were primary data. The analytical methods used included: descriptive analysis, profit analysis and R/C Ratio, and Chi-Square. The study showed that productivity and profitability of large-scale dairy farm was higher than small-scale. The performance of small-scale dairy farm of MPC members was relatively low both in terms of productivity and profitability. Most members judged that the performance of MPC services was good. There was a positive relationship between the MPC service performance (milk marketing, finance, technical assistance, and education/training) with the performance of dairy farm of MPC members. Coaching and more intensive services should continue to be given by the MPC to the members, especially the members with the small-scale dairy farms.
\end{abstract}

Keywords: service performance, milk producerscooperative, dairy farm

\section{ABSTRAK}

Tujuan utama dibentuknya Koperasi Produsen Susu (KPS) adalah untuk memberikan pelayanan kepada anggota dan meningkatkan kinerja usaha peternakan sapi perah anggota. Tujuan studi ini adalah: (1) menganalisis kinerja usaha ternak anggota KPS, (2) menganalisis kinerja pelayanan KPS, dan (3) menganalisis hubungan kinerja pelayanan KPS dengan kinerja usaha ternak sapi perah anggota. Data utama yang digunakan adalah data primer. Metode analisis yang digunakan meliputi: analisis deskriptif, analisis keuntungan, R/C Ratio, dan Chi-Square. Hasil studi menunjukkan bahwa produksi sapi laktasi dan profitabilitas usaha ternak sapi perah skala besar lebih tinggi dari skala kecil. Kinerja usaha ternak sapi skala kecil pada anggota KPS relative rendah baik dari segi produktivitas maupun profitabilitas. Sebagian besar anggota menilai bahwa kinerja pelayanan KPS sudah baik. Terdapat hubungan positif antara kinerja pelayanan KPS (pemasaran susu, pembiayaan, konsultasi, dan pendidikan/pelatihan) dengan kinerja usaha ternak anggota. Pembinaan dan pelayanan yang lebih intensif perlu terus diberikan oleh KPS kepada anggota, terutama anggota dengan usaha peternakan sapi perah skala kecil.

Kata kunci: kinerja pelayanan, koperasi produsen susu, usaha ternak sapi perah

\section{INTRODUCTION}

Dairy farm is one of the business activities in the livestock subsector that has the potential to be developed. The development of the population of dairy

*Corresponding author:

E-mail: allaasmara@yahoo.com; alla.asmara@gmail.com cattle and national milk production shows the better conditions indicated by the increase in the number of dairy cattle and the production each year. Ministry of Agriculture (2016) stated that dairy cow population in 2015 was as many as 518.650 cows and increased to 533.860 cows (provisional figure) in 2016. Meanwhile, milk production in 2015 was as much as 835.120 tons and increased to 852.950 tons (provisional figure) in 2016. 
In Indonesia, a dairy farm with small-scale business is the most dominant. This phenomenon is characterized by a pattern that is still traditional and family-based labor. Meanwhile, large-scale farming are generally managed with a better management and the use of labor from outside the family. Asmara et al. (2016) indicated a difference in the gains of dairy cattle business between small-scale and large-scale farms.

In conducting the business, generally farmers join the cooperative institutions. The Milk Producer Cooperative (MPC) is the primary cooperatives, which are at the sub-district level (for one sub-districts, there is only one cooperative) and organize dairy farmers who become members. Mazzarol et al. (2013) suggested that cooperatives could offer substantial value to their members in the form of access to resources, sharing of knowledge and information.

Cooperatives have the potential to have the competitiveness. Yang \& Liu (2012) stated that the farmer cooperative formed by a series of contracts and on the principle of reciprocity could reduce transaction costs. Kunte \& Patankar (2015) stated that cooperatives have positive impact on milk production and income generation. Furthermore, Khan et al. (2014) stated that the important role of dairy cooperatives in the marketing of milk and provided the necessary supports for dairy farmers leading to their socio-economic development.

However, the empirical evidence in Indonesia showed that the majority of dairy farms of cooperative members had not yet reached the level of income as expected. Kartikasari et al. (2015) showed that a dairy farm in the Cooperative Mahesa in Jember was not in accordance with the standards of agroecology and was not financially feasible. Meanwhile, Emawati (2011) stated that the investment in the dairy farm of the farmer members of Dairy Cattle Farm of Kaliurang Cooperative, Sleman was financially feasible. Astuti et al. (2010) revealed that farmer members of Kaliurang Cooperative were technically not rational (elasticity of production $(\mathrm{Ep})>1$ ) in the use of production factors. Departing from the phenomenon, the main question in this study is whether there is a relationship of service performance with the performance of cooperative dairy farm members. The objectives of this study were: (1) to analyze the dairy farm performance of MPC members, (2) to analyze the performance of MPC services, and (3) to analyze the relationship between the MPC service performances with business performance of members.

\section{METHODS}

The study was conducted in East Java and West Java as the centers of dairy cattle production in Indonesia. However, the different agro-ecosystems and socio-cultural conditions of farmers in the region were expected to bring their differences or diversities in the business pattern, which then affected the variability in the achievements of business performances.

For selected areas in East Java was Pasuruan, and for West Java was in Bandung. Those locations were chosen because those two locations were not only being the centers of dairy cattle production but also there were a number of MPCs that were relatively developed so that both locations were expected to be representative.

The main data used in the study were primary data. Those were collected through interviews using a questionnaire to the members of dairy cooperatives. The samples were selected by stratified random sampling method which was based on the scale of activities of livestock (small scale and large scale). A farmer was categorized into small scale when it had the number of lactating cows up to 5 heads and large scale if it had more than 5 lactating cows. The distribution of the sample based on the region and business scale is presented in Table 1.

Data collected were analyzed using descriptive analysis, analysis of profit and R/C Ratio, and ChiSquare analysis. Descriptive analysis were used to describe the characteristics of dairy farms and MPC service performance. MPC service performance was measured from the perspective of the farmer members by using Likert scale from 1 (very low) to 5 (high). Meanwhile, analysis of business profits and $\mathrm{R} / \mathrm{C}$ ratio was used to measure the performance of the livestock business carried on by members of the cooperative farmers. The formula for calculating the profit of business was as follows:

$$
\mathrm{TP}=\mathrm{TR}-\mathrm{TC} \text {. }
$$

where:

$\mathrm{TP}=$ Total profit $(\mathrm{Rp})$

$\mathrm{TR}=$ Total revenue $(\mathrm{Rp})$

$\mathrm{TC}=$ Total cost $(\mathrm{Rp})$

Meanwhile, R/C Ratio was the ratio of TR to TC. If the revenue that was achieved was lower than the cost of a business carried on, then the business was not profitable (loss) and vice versa. Thus, if the value of $\mathrm{R} / \mathrm{C}$ ratio was greater than one, then the business which carried on was already profitable, while if it's less than one, it meant that the business carried on was unprofitable. Analysis of the level of business profits and R/C Ratio was based on the cash costs and total costs.

Chi Square was used to analyze the relationship between the performance of cooperative's services (from the perspective of members) and business performance of livestock cooperative members. Hypotheses for testing were:

Ho: performance of cooperatives service and perfor-

Table 1. Distribution of respondents by region and business scale

\begin{tabular}{lccc}
\hline Location & $\begin{array}{c}\text { Small } \\
\text { scale }\end{array}$ & $\begin{array}{c}\text { Large } \\
\text { scale }\end{array}$ & Total \\
\hline Bandung District, West Java: & 37 & 33 & 70 \\
a. KPBS Pangalengan & 19 & 15 & 34 \\
b. KPSBU Lembang & 18 & 18 & 36 \\
Pasuruan District, East Java: & 33 & 30 & 63 \\
a. KUTT Suka Makmur & 16 & 15 & 31 \\
b. KPSP Setia Kawan & 17 & 15 & 32 \\
Total & 70 & 63 & 133 \\
\hline
\end{tabular}

Note: Small scale= the ownership of lactating cows up to 5 heads; Large scale $=$ the ownership of lactating cows more than 5 heads. 
mance of farm business members is independent (There is no association)

$\mathrm{Hi}$ : performance of cooperative service and the performance of the livestocks business members are dependent (There is association)

Territory criticism for hypothesis testing were:

If $\chi_{\text {account }}^{2} \geq \chi_{\alpha(v)}^{2}$ then Ho was not accepted

If $\chi_{\text {account }}^{2}<\chi_{\alpha(\mathrm{v})}^{2}$ then Ho was accepted

$(\alpha=$ significance level, $\mathrm{v}=$ degree of freedom $)$

The formula to calculate Chi Square was as follows:

$$
\chi_{\text {account }}^{2}=\sum_{i=1}^{r} \sum_{j=1}^{c} \frac{\left(O_{i j}-E_{i j}\right)^{2}}{E_{i j}}
$$

where:

$\mathrm{O}_{\mathrm{ij}}=$ the observations frequency in the row $\mathrm{i}$ and column j

$\mathrm{E}_{\mathrm{ij}}=$ The theoretical frequency (expectations) in the row $\mathrm{i}$ and column $j$

To calculate the theoretical frequency used the formula:

$$
E_{i j}=\frac{\left(T_{i} \cdot\right)\left(T \cdot_{j}\right)}{T . .}
$$

where $T_{i}$. was the total of frequency in the row $i, T_{. j}$ was the total of frequency in the coloumn $j$, and $T$.. was the total frequency of observations.

\section{RESULTS}

\section{Milk Producers Cooperative Profiles in the Study} Areas

The number of members of the four cooperatives samples is presented in Table 2. Based on the table, it was known that the number of members in each MPC was likely to increase, unless the KPBS Pangalengan which tended to decrease.

Unlike the member development, the development of the cattle population in the KPBS Pangalengan was increased. However, milk production was decreased. The decline in milk production was also occurred in KPSP Setia Kawan Nongkojajar. The decline was in line with the decline in population. It was an indication that the business of dairy cattle run by the members was not able to develop as expected. Meanwhile, for the two other cooperatives (KPSBU Lembang and KUTT Suka
Makmur) the population and milk production were increased (Table 3).

Furthermore, the business units run by MPC are presented in Table 4. Based on the table, it was known that the business-related services and marketing milk production was the main business unit which became the core business of MPC.

\section{Characteristics and Business Performance of Dairy Farm of MPC Members}

The results of analysis on the characteristics and performance of dairy farm of MPC members showed that the dairy farms of the MPC members in West Java were better than in East Java (Table 5).

However, Table 6 showed that although the productivity of dairy farm of the MPC members in West Java was relatively high, the profitability of its business, as measured by the value of $\mathrm{R} / \mathrm{C}$ ratio (the ratio of revenue to costs, cash costs in particular) in East Java was higher than in West Java. The facts also showed that in both provinces, profitability of large-scale dairy farm was greater than the small-scale dairy farm, almost twice as much.

\section{Milk Producers Cooperative (MPC) Services Performance from Member Perspective}

The results of the analysis of the MPC service performance according to the members perception are shown in Table 7 . The tables showed that in general

Table 2. The development of milk producers cooperative (MPC)

\begin{tabular}{|c|c|c|}
\hline \multirow[t]{2}{*}{ Cooperative } & \multicolumn{2}{|c|}{$\begin{array}{c}\text { Members } \\
\text { development }\end{array}$} \\
\hline & 2014 & 2015 \\
\hline \multicolumn{3}{|l|}{ West Java } \\
\hline KPBS Pangalengan & 5,050 & 4,813 \\
\hline KPSBU Lembang & 7,091 & 7,190 \\
\hline \multicolumn{3}{|l|}{ East Java } \\
\hline KUTT SukaMakmur & 2,259 & 2,744 \\
\hline KPSP Setia Kawan Nongkojajar & 8,252 & 8,484 \\
\hline
\end{tabular}
members in the study area

Source: Reports of each cooperative

\begin{tabular}{|c|c|c|c|c|}
\hline \multirow{2}{*}{ Primary cooperative } & \multicolumn{2}{|c|}{ Dairy population development (head) ${ }^{*}$} & \multicolumn{2}{|c|}{ Production development (L) } \\
\hline & 2014 & 2015 & 2014 & 2015 \\
\hline \multicolumn{5}{|l|}{ West Java } \\
\hline KPBS Pangalengan & 12,439 & 12,703 & $27,869,978.58$ & $27,500,473.21$ \\
\hline KPSBU Lembang & 17,816 & 18,583 & $47,379,932.50$ & $54,596,314.00$ \\
\hline \multicolumn{5}{|l|}{ East Java } \\
\hline KUTT Suka Makmur & 13,588 & 13,703 & $21,052,231.00$ & $22,262,883.30$ \\
\hline KPSP Setia Kawan Nongkojajar & 17,622 & 17,302 & $25,971,448.00$ & $27,694,037.00$ \\
\hline
\end{tabular}

Tabel 3. The development of dairy population and milk production of milk producers cooperative (MPC) in the study area

Note: * dairy population includes lactating and non lactating cow. 
Table 4. Milk producers cooperative (MPC) business development in the study area

\begin{tabular}{ll}
\hline \multicolumn{1}{c}{ Primary cooperative } & \multicolumn{1}{c}{ Cooperative business developments } \\
\hline $\begin{array}{l}\text { West Java } \\
\text { KPBS Pangalengan }\end{array}$ & $\begin{array}{l}\text { (1) Unit of production services (2) Unit of processing and marketing services (3) Unit of goods } \\
\text { services, feed and vehicles (4) Unit of feed processing (5) Unit of nursery and HMT services } \\
\text { (6) Unit of veterinary services and member (7) Unit of PT. BPR Bandung Kidul }\end{array}$ \\
KPSBU Lembang & $\begin{array}{l}\text { (1) Production (2) Marketing and milk quality (3) Feed concentrates (4) Processing of milk (5) } \\
\text { Waserda (6) Cattle farming (7) Credit }\end{array}$ \\
East Java & $\begin{array}{l}\text { (1) Unit of agri-service (2) Unit of Kejayaan PMT (3) Unit of savings and loans (4) Unit of SP2T } \\
\text { KUTT Suka Makmur }\end{array}$ \\
(5) Unit of G-Mart (6) Unit of G-Logistic \\
KPSP Setia Kawan Nongkojajar & (1) Division of fresh milk (2) Savings and loans (3) Trade and services.
\end{tabular}

Table 5. The average number of dairy cattle and the performance of milk production of the milk producers cooperative (MPC) members in the study area

\begin{tabular}{|c|c|c|c|c|}
\hline \multirow{2}{*}{ Description } & \multicolumn{2}{|c|}{ West Java } & \multicolumn{2}{|c|}{ East Java } \\
\hline & 1 & 2 & 1 & 2 \\
\hline The average ownership of lactating cow (head) & 2.59 & 9.79 & 1.82 & 8.03 \\
\hline The average ownership of total dairy cow (head) & 5.71 & 16.58 & 4.48 & 11.83 \\
\hline The average production (L/cow/day) & 13.03 & 14.24 & 10.5 & 10.97 \\
\hline Calving interval (day) & 409 & 403 & 411 & 405 \\
\hline Service per conception & 2.88 & 2.15 & 2.34 & 2.22 \\
\hline Length of lactation (day) & 295 & 307 & 305 & 305 \\
\hline The price of milk $(\mathrm{Rp} / \mathrm{L})$ & 4309 & 4438 & 4564 & 4640 \\
\hline The price of concentrate $(\mathrm{Rp} / \mathrm{kg})$ & 3350 & 3345 & 4564 & 4603 \\
\hline
\end{tabular}

Note: $1=$ small scale (ownership of lactating cows up to 5 heads); $2=$ large scale (ownership of lactating cows more than 5 heads)

Table 6. Analysis of profit and R/C ratio farming business of milk producers cooperative (MPC) members in the study area

\begin{tabular}{|c|c|c|c|c|c|c|c|c|}
\hline \multirow{3}{*}{$\begin{array}{l}\text { Cost and revenue from } \\
\text { farm bussines }\end{array}$} & \multicolumn{4}{|c|}{ West Java } & \multicolumn{4}{|c|}{ East Java } \\
\hline & \multicolumn{2}{|c|}{ Small Scale } & \multicolumn{2}{|c|}{ Large Scale } & \multicolumn{2}{|c|}{ Small Scale } & \multicolumn{2}{|c|}{ Large Scale } \\
\hline & $(\mathrm{Rp})$ & $\%$ & $(\mathrm{Rp})$ & $\%$ & $(\mathrm{Rp})$ & $\%$ & $(\mathrm{Rp})$ & $\%$ \\
\hline A. Total revenue & $61,380,909$ & & $262,545,807$ & & $34,190,000$ & & $145,205,125$ & \\
\hline B. Cash cost & $49,414,509$ & 48.82 & $113,629,489$ & 56.13 & $24,834,672$ & 38.2 & $59,669,720$ & 56.78 \\
\hline 1. Labor & $7,945,833$ & 7.85 & $12,679,720$ & 6.26 & 0 & 0 & $11,764,622$ & 11.2 \\
\hline 2. Forage & $6,956,709$ & 6.87 & $15,127,436$ & 7.47 & $3,769,032$ & 5.8 & $5,139,152$ & 4.89 \\
\hline 3. Additional feed & $1,161,364$ & 1.15 & $6,169,250$ & 3.05 & $1,508,960$ & 2.32 & $3,632,761$ & 3.46 \\
\hline 4. Concentrate & $33,125,603$ & 32.73 & $79,428,083$ & 39.24 & $18,928,444$ & 29.11 & $38,441,367$ & 36.58 \\
\hline 5. Drugs & 225,000 & 0.22 & 225,000 & 0.11 & 628,235 & 0.97 & 691,818 & 0.66 \\
\hline C. Non-cash cost & $51,801,503$ & 51.18 & $88,796,888$ & 43.87 & $40,185,279$ & 61.8 & $45,416,475$ & 43.22 \\
\hline 1. Labor & $15,891,667$ & 15.7 & $19,019,580$ & 9.4 & $19,781,818$ & 30.42 & $14,705,778$ & 13.99 \\
\hline 2. Forage & $20,870,127$ & 20.62 & $45,382,307$ & 22.42 & $11,307,097$ & 17.39 & $15,417,455$ & 14.67 \\
\hline $\begin{array}{l}\text { 3. Depreciation of } \\
\text { investments per year }\end{array}$ & $15,039,709$ & 14.86 & $24,395,000$ & 12.05 & $9,096,364$ & 13.99 & $15,293,241$ & 14.55 \\
\hline D. Total cost $(B+C)$ & $101,216,012$ & 100.00 & $202,426,377$ & 100.00 & $65,019,950$ & 100.00 & $105,086,194$ & 100.00 \\
\hline E. Cash income (A - B) & $11,966,400$ & & $148,916,318$ & & $9,355,328$ & & $85,535,405$ & \\
\hline F. Total income (A - D) & $-39,835,103$ & & $60,119,430$ & & $-30,829,950$ & & $40,118,931$ & \\
\hline \multicolumn{9}{|l|}{ R/C Ratio: } \\
\hline - to the cash cost & 1.24 & & 2.31 & & 1.38 & & 2.43 & \\
\hline - to the total cost & 0.61 & & 1.30 & & 0.53 & & 1.38 & \\
\hline
\end{tabular}


Tabel 7. Assessment distribution of respondents on services performance of milk producers cooperative (MPC) and cross tabulation with dairy farm business performances of MPC member

\begin{tabular}{|c|c|c|c|c|c|c|c|c|}
\hline \multirow{4}{*}{ Service performance } & \multicolumn{8}{|c|}{ Business performance (\%) } \\
\hline & \multicolumn{4}{|c|}{ West Java } & \multicolumn{4}{|c|}{ East Java } \\
\hline & \multicolumn{2}{|c|}{ Small scale } & \multicolumn{2}{|c|}{ Large scale } & \multicolumn{2}{|c|}{ Small scale } & \multicolumn{2}{|c|}{ Large scale } \\
\hline & Profits & Loses & Profits & Loses & Profits & Loses & Profits & Loses \\
\hline \multicolumn{9}{|l|}{ Provision of Inputs } \\
\hline - Low performance & 21.21 & 15.15 & 10.00 & 13.33 & 3.03 & 3.03 & 6.67 & 13.33 \\
\hline - Medium Performance & 21.21 & 30.30 & 20.00 & 26.67 & 60.61 & 12.12 & 23.33 & 43.33 \\
\hline - High performance & 6.06 & 6.06 & 6.67 & 23.33 & 18.18 & 3.03 & 3.33 & 10.00 \\
\hline \multicolumn{9}{|l|}{ Financing } \\
\hline - Low performance & 24.24 & 18.18 & 3.33 & 10.00 & 6.06 & 3.03 & 6.67 & 0.00 \\
\hline - Medium performance & 18.18 & 12.12 & 10.00 & 30.00 & 54.55 & 12.12 & 16.67 & 46.67 \\
\hline - High performance & 6.06 & 21.21 & 23.33 & 23.33 & 21.21 & 3.03 & 10.00 & 20.00 \\
\hline \multicolumn{9}{|l|}{ Marketing } \\
\hline - Low performance & 6.06 & 21.21 & 3.33 & 16.67 & 3.03 & 0.00 & 6.67 & 0.00 \\
\hline - Medium performance & 39.39 & 18.18 & 20.00 & 40.00 & 57.58 & 15.15 & 26.67 & 40.00 \\
\hline - High performance & 3.03 & 12.12 & 13.33 & 6.67 & 21.21 & 3.03 & 0.00 & 26.67 \\
\hline \multicolumn{9}{|l|}{ Consultacy } \\
\hline - Low performance & 9.09 & 27.27 & 0.00 & 16.67 & 33.33 & 3.03 & 16.67 & 13.33 \\
\hline - Medium performance & 33.33 & 21.21 & 33.33 & 33.33 & 42.42 & 12.12 & 16.67 & 50.00 \\
\hline - High performance & 6.06 & 3.03 & 3.33 & 13.33 & 6.06 & 3.03 & 0.00 & 3.33 \\
\hline \multicolumn{9}{|l|}{ Training } \\
\hline - Low performance & 15.15 & 21.21 & 3.33 & 20.00 & 27.27 & 0.00 & 23.33 & 33.33 \\
\hline - Medium performance & 24.24 & 27.27 & 23.33 & 40.00 & 45.45 & 15.15 & 10.00 & 30.00 \\
\hline - High performance & 9.09 & 3.03 & 10.00 & 3.33 & 9.09 & 3.03 & 0.00 & 3.33 \\
\hline
\end{tabular}

the MPC members in East Java and West Java assessed that the services provided by the MPC to the members for all of its services were good. Most of the members considered that MPC's service delivery in terms of input provision, financing, marketing, consultation, and training had medium and high performances.

\section{The Relationship Between MPC Services Performance with Performance of Dairy Farm of MPC Members}

Results of the analysis of the relationship between MPC service performance and dairy farm performance of MPC members are shown in Table 8. The result of Chi-square analysis showed that there was a difference in relationship between MPC service with dairy farm performance of the MPC members between East Java and West Java as well as between small and large scale. In East Java, MPC service performance only affected large scale dairy farm performance and did not affect small-scale dairy farm performance. While in West Java, MPC service performance influenced both small and large-scale dairy farm performed differently.

\section{DISCUSSION}

\section{Characteristics and Business Performance of Dairy Farm of MPC Members}

Productivity of the milk produced is the main characteristics of the production, as already in Table 5. The
Table 8. Chi-Square values between performances of cooperative service and performances of farming cooperative members

\begin{tabular}{|c|c|c|c|c|}
\hline \multirow{4}{*}{ Services } & \multicolumn{4}{|c|}{ Cattle business performance } \\
\hline & \multicolumn{2}{|c|}{ West Java } & \multicolumn{2}{|c|}{ East Java } \\
\hline & $\begin{array}{c}\text { Small } \\
\text { scale }\end{array}$ & $\begin{array}{l}\text { Large } \\
\text { scale }\end{array}$ & $\begin{array}{c}\text { Small } \\
\text { scale }\end{array}$ & $\begin{array}{c}\text { Large } \\
\text { scale }\end{array}$ \\
\hline & $\mathrm{X} 2$ & $\mathrm{X} 2$ & $\mathrm{X} 2$ & $\mathrm{X} 2$ \\
\hline $\begin{array}{l}\text { Provision of } \\
\text { inputs }\end{array}$ & 0.833 & 1.155 & 1.470 & 0.150 \\
\hline Financing & $3.436^{*}$ & 2.010 & 0.637 & $4.421^{*}$ \\
\hline Marketing & $7.133^{* *}$ & $3.445^{*}$ & 0.509 & $8.400^{* *}$ \\
\hline $\begin{array}{l}\text { Technical } \\
\text { assistance }\end{array}$ & $7.446^{* *}$ & $39.569^{* * *}$ & 3.082 & 3.125 \\
\hline $\begin{array}{l}\text { Training/ } \\
\text { Education }\end{array}$ & 1.363 & $4.041^{*}$ & 2.750 & 1.346 \\
\hline
\end{tabular}

Note: ${ }^{* *}$ Significance level of $\alpha=1 \% ;{ }^{*}$ Significance level of $\alpha=5 \%$; *Significance level of $\alpha=20 \%$.

average production per lactating cow in large scale was slightly higher than small scale and the average production per lactating cow in West Java was slightly higher than in East Java. This indicates that the dairy farm business management of large scale is better than small scale and the dairy farm business management in West Java is better than in East Java. The relatively high average production per lactating cow in West Java is supported by 
good reproductive condition (calving interval, service per conception, and long lactation).

Factors affecting the milk production are stated in the studies reported by Weglarzy (2009) and Pasaribu et al. (2016). Weglarzy (2009) stated that lactation productivities of dairy cows were affected by the length of preceding dry period. Pasaribu et al. (2016) stated that variations in milk production of dairy were determined by variations in the amount of feed, the amount of drinking water, the age of livestock, the size of the cowshed, and the milking interval.

The other findings of the characteristic of the dairy farm are profitability or Revenue-Cost analysis (Table 6). The first finding was that although the productivity of dairy farm of the MPC members in West Java was relatively high, but the profitability of its business, in East Java was higher than in West Java. The value of R/C ratio (cash costs in particular) of dairy farm of MPC members in East Java reached 1.38 and 2.43, respectively, for each of the small-scale and large-scale business; while in West Java for a similar business scale, the $\mathrm{R} / \mathrm{C}$ ratio only reached 1.24 and 2.31 .

The second finding related to the profitability of the dairy farm was that in both provinces, profitability of large-scale dairy farm was greater than that of smallscale dairy farm, almost twice as much; even if the non-cash expenses were taken into account, small-scale dairy farm was not profitable, meanwhile large-scale dairy farm still had a positive profit. If all costs were taken into account, small-scale dairy farm got a negative gain (loss) with the value of R/C of 0.53 in East Java and 0.61 in West Java. These results implied that for every 1 rupiah costs, it will only gain 0.53 rupiah of revenue for small-scale dairy farm in East Java and it will only gain 0.61 rupiah of revenue for small-scale dairy farm in West Java.

The results of this study confirm that small-scale businesses have poorer performance than large-scale businesses, although the service cooperatives received were same. Thus, the differences of profit between small and large scale dairy farm are due to the differences in business management. Small-scale farmers generally run the business with a pattern as was done by previous generations. Limitations in the capital owned causes the production inputs is not used properly. Concentrate feed is often replaced with other feed ingredients with lower qualities such as bran or tofu. Meanwhile, largescale farmers run the business with a better management system. In addition, large-scale farmers provide forage and concentrates with a good quality and apply the recommended technology of livestock farming. Moran (2009) stated that high quality forages and concentrates are essential for profitable dairy farm.

These results were also consistent with the analysis of efficiency which showed that large-scale businesses were relatively more efficient than small-scale businesses (Asmara et al., 2016). The results of Herrero et al. (2010) and Masuku et al. (2014), also revealed that one of the factors that significantly affected economic efficiency of dairy farmers was herd size or the number of dairy cattle ownership with a positive impact. Related to business profit, Sari et al. (2013) stated that the dairy farm was not profitable. Meanwhile, Halolo et al. (2013a) stated that the dairy farm business was profitable and Halolo et al. (2013b) stated that the dairy farm was efficient. Santosa et al. (2013) revealed that the R/C ratio of dairy farm was 1.28.

In accordance with the previous description that analyzes the differences in the rate of profit and $\mathrm{R} / \mathrm{C}$ ratio on the small scale and large scale businesses indicated that the results of this study confirm the findings of previous studies. The results of this study were able to show that the business of dairy farm run by MPC members get benefit ( $\mathrm{R} / \mathrm{C}$ ratio $>1)$ and some suffer losses $(\mathrm{R} / \mathrm{C}$ ratio $<1)$.

The fact in this study that the profitability of small and large scale dairy farm in East Java was higher than in West Java is possible because the cost of dairy farm in East Java is relative smaller than in West Java (Table 6). Meanwhile, the output price in East Java was higher than in West Java (Table 5).

Based on the comparison of revenue and cash cost, it was known that the cash cost portion reaches $80.5 \%$ and $43.3 \%$ for small scale and large scale in West Java. While in East Java, the share of cash cost on revenues was $72.6 \%$ in small scale and $41.1 \%$ in large scale dairy farms. With the share of these costs, the profit of dairy farm in East Java was relatively more profitable than in West Java. The cost of purchasing concentrates was the largest cash costs in the dairy farm

Differences in profit between West Java and East Java, are not only due to differences in costs but also differences in output prices. The effects of cost and output price on profit are also expressed by Kristoro (2014). Kristoro (2014) stated that dairy farm in Semarang Regency was feasible. Nevertheless, the low selling price at farmers level and the high cost of milk production makes the farmers gain little profit.

Meanwhile, Saha (2014) stated that the dairy farm had a lot of potential to improve rural incomes, nutrition, and women empowerment, and hence it was a very critical area for investment. In line with Saha (2014), Kusnadi \& Juarini (2007) revealed that the increase of income in the dairy farm could be done through the implementation of economical dairy farm management.

\section{Milk Producers Cooperative (MPC) Services Performance from Member Perspective}

The result in Table 7 showed that most of the MPC members in both West Java and East Java felt that the performance of services provided by the cooperative already excellent (middle-high performance). These finding was in line with the studies of Nugroho \& Dedi (2011), Nurfitriani \& Husnah (2013), and Liang et al. (2015).

The results of study conducted by Nugroho \& Dedi (2011) showed that the dairy cooperatives had a good performance on the financial aspects and institutional. Nurfitriani \& Husnah (2013) concluded that there was a positive correlation between governance and cooperative performance. Liang et al. (2015), stated 
that each dimension of social capital had a significant and positive impact on the economic performances of cooperatives.

\section{The Relationship Between MPC Services Performance with Performance of Dairy Farm of MPC Members}

Result of analysis showed that there was a relationship between the performances of MPC services to the dairy farm performance of the members (Table 8). The relationship between the variables of service performance and the performance of businesses member found either on cooperative members with small scale or large-scale, except for the small-scale farming in East Java. Result of that study is supported by others studies, Tanwar et al. (2015), McRoberts et al. (2013) and Phadi (2014).

Tanwar et al. (2015) showed that annual milk production and annual net income were significantly higher in cooperative members compared to non-cooperative member. McRoberts et al. (2013) concluded that the cooperative potentially could increase community incomes while controlling risk under a range of environmental and market conditions.. Meanwhile, Phadi (2014) stated that the dairy cooperatives play an important role for rapid development of rural people.

Chi-square analysis result also showed that there is different types of MPC services that affect the dairy farm performance of inter-scale business and interregion. However, all dairy farms of small and large scale businesses, in West Java and East Java were influenced by the marketing service of The MPC. This result in line with Kavoi et al. (2010) which states that one of the key avenues for increasing efficiency for smallholder dairy cattle is to address the institutional and socio economic infrastructure.

Marketing milk, financing, consulting, and training for members are cooperative services that have a relationship with the member's business performance. Provision of input service has no significant corelationship to the dairy farm of the members, meanwhile marketing is an MPC service that has an effect on all dairy farms in West Java and East Java. Services in marketing milk that provides convenience and certainty of the market and the price is reasonable for members to sell the products (milk) produced that will provide an incentive for members to increase production.

Priyono \& Priyanti (2015) states that strengthening of dairy cooperatives in dairy cattle area is quite effective in supporting the development of dairy cattle population and milk production because the cooperative institution is one of marketing nodes of milk that has a strategic role. Asih et al. (2013) indicates that the existence of cooperatives as a core industry in the dairy industry cluster in Semarang Regency has a big role in the marketing of milk.

Meanwhile, with the services of consulting and training provided by the cooperative, it is hoped, will improve the knowledge and skills of cooperative members in carrying out his business. According to Sheela \& Ramegowda (2013), more training should be given to stimulate interests and commitment of members. Utami et al. (2014) stated that the role of cooperatives will affect the performance of cooperative members in producing quality milk.

Capital constraints often make the cooperative members are not able to do business development. Therefore, the service in terms of capital will help the members of the cooperative in meeting capital requirements. The cooperative is one of alternative source of financing for dairy farm because the constraints faced. Study of Sulistyati et al. (2013) describes the importance of the capital to encourage their dairy farms.

\section{CONCLUSION}

In general, the performance of the dairy farms of the MPC members measured by productivity and profitability still needs to be improved. Productivity and profitability of large-scale dairy farm was higher than small-scale. Performance of small-scale dairy farm of the MPC members was relatively low both in terms of profitability and productivity. Profitability of dairy farm in East Java was higher than in West Java. Based on the members' perception, most of members judge that the performance of MPC services (provision of input, financing, marketing, technical assistance and training) was good (middle and high performances), but there was little difference in the assessment between regions and between scale of the dairy farms. There was a positive relationship between the MPC service performance (milk marketing, finance, technical assistance, and education/training) with the performance of dairy farms of MPC members, but only marketing service that affects the dairy farm in both East Java and West Java and both small and large-scale dairy farms. Coaching and more intensive services should continue to be given by the MPC to the members, especially the members with the small-scale dairy farms.

\section{REFERENCES}

Asih, R., T. W. Murti, \& F. T. Haryadi. 2013. Dynamics of dairy industry cluster development in Semarang Regency, Central Java. Article in Indonesian. Buletin Peternakan 37: 59-66. https://doi.org/10.21059/buletinpeternak.v37i1.1960

Asmara, A., Y. L. Purnamadewi, \& D. Lubis. 2016. Keragaan produksi susu dan efisiensi usaha peternakan sapi perah rakyat di Indonesia. Jurnal Manajemen \& Agribisnis 13: 14-25. https://doi.org/10.17358/JMA.13.1.14

Astuti, M., R. Widiati, \& Y. Y. Suranindyah. 2010. Production efficiency of smallholder dairy cattle farming (Case study on the farmer members of dairy cattle farm of Kaliurang Cooperative, Sleman, Yogyakarta). Article in Indonesian. Buletin Peternakan 34: 64-69. https://doi.org/10.21059/buletinpeternak.v34i1.108

Emawati, S. 2011. Profitability of dairy cattle farm in Sleman District. Article in Indonesian. Sans Peternakan 9: 100108. https://doi.org/10.20961/sainspet.9.2.100-108

Halolo, R. D., S. I. Santoso, \& S. Marzuki. 2013a. Analisis profitabilitas pada usaha peternakan sapi perah di Kabupaten Semarang. Jurnal Pengembangan Humaniora 13: 65-72.

Halolo, R. D., S. I. Santoso, \& S. Marzuki. 2013b. Efisiensi usaha peternakan sapi perah di Kabupaten Semarang. Agromedia 31: 1-8.

Herrero, M., S. K. Nganga, J. Kungu, \& N. de Ridder. 2010. 
Profit efficiency among Kenyan smallholder milkproducers: A case study of Meru-South District, Kenya. African Journal of Agricultural Research 5: 332-337.

Kartikasari, C. A., Soetriono, \& E. B. Koentadi. 2015. Analisis kelayakan finansial dan strategi pengembangan peternakan sapi perah pada Koperasi Mahesa di Kabupaten Jember. Berkala Ilmiah Pertanian x: 1-10.

Kavoi, M. M., D. L. Hoag, \& J. Pritchett. 2010. Measurement of economic efficiency for smallholder dairy cattle in the Marginal Zones of Kenya. Journal of Development and Agricultural Economics 2: 122-137.

Khan, N., A. K. Parashari, \& M. S. Salman. 2014. Role of dairy co-operatives in socio-economic development of dairy farmers in Moradabad District: a case study. International Journal of Social Sciences 2: 1-8).

Kristoro, A. 2014. Analisis profit marjin susu sapi perah di Kecamatan Ungaran Kabupaten Semarang. Economics Development Analysis Journal 3: 345-354.

Kunte, B. S. \& S. Patankar. 2015. A literature review of Indian Dairy Industry. International Journal of Management Research \& Review 5: 341-350.

Liang, Q., Z. Huang, H. Lu, \& X. Wang. 2015.Social capital, member participation, and cooperative performance: Evidence from China's Zhejiang. International Food and Agribusiness Management Review 18: 49-78.

Masuku, B. B., M. B. Masuku, \& A. Belete, 2014. Economic efficiency of smallholder dairy farmers in Swaziland: An application of the profit function. Journal of Agricultural Studies 2: 132-146. https://doi.org/10.5296/jas.v2i2.6046

Mazzarol, T., E. M. Limnios, \& S. Reboud. 2013. Co-operatives as a strategic network of small firms: Case studies from Australian and French co-operatives. Journal of Cooperative Organization and Management 1: 27-40. https:// doi.org/10.1016/j.jcom.2013.06.004

McRoberts, K. C., C. F. Nicholson, R. W. Blake, T. W. Tucker, \& G. D. Padilla. 2013. Group model building to assess rural dairy cooperative feasibility in South-Central Mexico. International Food and Agribusiness Management Review16: 55-98.

Ministry of Agriculture. 2016. Populasi dan Produksi Peternakan di Indonesia. http: //www.pertanian.go.id/ Indikator/tabel-4-pop-prod-nak.pdf. [15 February 2017].

Nugroho, B. A. \& Dedi. 2011. The analysis of balanced scorecard (BSC) in evaluating the performance of KUD "DAU" Malang. Article in Indonesian. Agrise XI:65-80.
Nurfitriani, S. \& N. Husnah. 2013.Analisis tata kelola dan kinerja koperasi peternak sapi di Jawa Barat. Jurnal Pengkajian Koperasi dan UKM 8: 41-57.

Pasaribu, A., Firmansyah, \& N. Idris. 2016. Analisis faktorfaktor yang mempengaruhi produksi susu sapi perah di Kabupaten Karo Provinsi Sumatera. Jurnal Ilmu-Ilmu Peternakan XVIII: 28-35.

Phadi, P. K. 2014. Growth and development of Indian dairy sector: A pragmatic analysis. Pacific Business Review International 7: 81-85.

Priyono \& A. Priyanti. 2015. Strengthening Dairy Cooperative through National Development of Livestock Region. Article in Indonesian.Wartazoa 25: 85-94.

Saha, G. K. 2014. Milk marketing in North East India: Experiences from Assam. The International Journal Of Business \& Management 2: 112-117.

Santosa, S. I., A. Setiadi, \& R. Wulandari. 2013. Potential Analysis of Dairy Cattle development through agribusiness paradigm in Musuk Sub District Boyolali Regency. Article in Indonesian. Buletin Peternakan 37: 125-135. https://doi.org/10.21059/buletinpeternak.v37i2.2431

Sari, D. R., S. Anantanyu, \& Suprapto. 2013. Analisis usaha tani ternak sapi perah Kecamatan Getasan Kabupaten Semarang. Jurnal Agrista 1: 1-12.

Sheela K. S. \& A. Ramegowda. 2013. Dairy cooperatives and empowerment of women. International Journal of Advanced Social Science and Humanities 2: 034-042.

Sulistyati, M., Hermawan, \& A. Fitriani. 2013. Potential of small scale dairy farm for facing in global market. Article in Indonesian. Jurnal Ilmu Ternak 13: 17-23.

Tanwar, P. S., Y. Kumar, \& G. S. Aulakh. 2015. Impact of dairy cooperatives on milk production, income and employment generation in Semi Arid Rajasthan. International Journal in Management and Social Science 3: 477-487.

Utami, K. B., L. E. Radiati, \& P. Surjowardojo. 2014. Kinerja peternak sapi perah PFH (Studi kasus pada anggota Koperasi Agro Niaga) di Kecamatan Jabung Kabupaten Malang. Jurnal Ilmu-Ilmu Peternakan 24: 61-68.

Weglarzy, K. 2009. Lactation productivity of dairy cows as affected by the length of preceding dry period. Animal Science Papers and Reports 27: 303-310.

Yang, D. \& Z. Liu. 2012. Study on the Chinese farmer cooperative economy organizations and agricultural specialization. Agric. Econ. 58: 135-146. 